\title{
HUBUNGAN ANTARA LINGKUNGAN SEBAYA DENGAN PERILAKU MEROKOK REMAJA DI SMAN X TASIKMALAYA TAHUN 2013
}

Oleh :

Setiawan, SH, M.Kes

\section{A. Abstrak}

Riskesdas tahun 2010 melaporkan bahwa rata-rata umur mulai merokok secara nasional adalah 17,6 tahun dengan persentase penduduk yang mulai merokok tiap hari terbanyak pada umur 15-19 tahun. Mayoritas prevalensi penduduk yang merokok adalah perokok yang memiliki umur 15 tahun ke atas yang merokok tiap hari secara nasional adalah 28,2 persen. Sebagaimana perokok setiap hari, prevalensi perokok kadangkadang tertinggi pada kelompok umur 15-24 tahun (8,1\%) dan cenderung menurun dengan bertambahnya umur (Riskesdas, 2010). Dari berbagai data di atas dapat disimpulkan bahwa pada umumnya usia memulai merokok diawali pada masa remaja. Tujuan dari penelitian ini adalah mengetahui hubungan antara faktor lingkungan sebaya dengan perilaku merokok pada siswa SMA X di Kabupaten Tasikmalaya tahun 2013.

Jenis Penelitian yang digunakan adalah kuantitatif dengan desain cross sectional. Populasi adalah seluruh siswa SMA X. Cara pengambilan sampel dengan menggunakan teknik acak stratifikasi (Stratified random sampling). Penentuan strata berdasarkan tingkatan kelas yaitu ;. Jumlah sampel 320 sampel.Pengumpulan data dilakukan dengan menggunakan alat bantu angkelt kuesioner yang diisi langsung oleh responden. Analisis yang dilakukan diawali dengan analisis univariat, kemudian dilanjutkan dengan analisis bivariat menggunakan uji chi square

Hasil penelitian didapatkan bahwa sebagian besar responden penelitian ini tergolong bukan perokok serta 320 orang responden 155 (48,4\%) memiliki lingkungan sebaya yang tergolong baik; sedangkan 165 (51,6\%) memiliki lingkungan sebaya yang tergolong tidak baik. Hasil analisis hubungan antara lingkungan teman sebaya dengan perilaku merokok diperoleh bahwa ada sebanyak 22 (42,3\%) remaja dengan lingkungan teman sebaya baik sebagai perokok, sedangkan di antara remaja dengan lingkungan teman sebaya tidak baik ada 48 (60,8\%) perokok. Hasil uji statistik diperoleh nilai $p=0,058$ maka dapat disimpulkan tidak ada hubungan yang signifikan antara lingkungan teman sebaya dengan perilaku merokok pada remaja.

Saran yang direkomendasikan adalah optimalisasi orang tua dalam memberikan contoh, kemampuan mengontrol teman sebaya serta berkontribusi langsung dalam pendidikan moral kepada anaknya.

\section{Kata Kunci : Perilaku merokok, remaja dan teman sebaya}




\section{B. Latar belakang}

Departemen Kesehatan Republik Indonesia (Depkes RI, 2008) melaporkan bahwa adanya hubungan kausal antara penggunaan rokok dengan terjadinya berbagai penyakit kanker, penyakit jantung, penyakit sistem saluran pernapasan, penyakit gangguan reproduksi dan kehamilan. Risiko berbagai penyakit tersebut disebabkan pada setiap batang rokok mengandung lebih dari 4000 bahan kimia toksik dan 43 bahan penyebab kanker karsinogenik). Merokok tidak hanya berbahaya bagi perokok tetapi juga orang di sekitarnya yang terkena asap rokok. Menurut Sarifuddin (2010), asap rokok sangat berbahaya karena semakin besar terpapar asap rokok semakin besar pula peluang kerusakan DNA. Semakin besar kerusakan DNA, maka semakin besar pula risiko terkena penyakit kanker dan serangan jantung.

Menurut Soamole (2004), setiap tahun ada empat juta orang yang meninggal akibat kebiasaan merokok. Dikhawatirkan, apabila penanganan yang tidak memadai maka di tahun 2030 diperkirakan proporsi perokok sebesar 1,6 miliar perokok, diantaranya sekitar 770 juta anak yang menjadi perokok pasif dan $85 \%$ terdapat di negara berkembang. Diperkirakan juga proporsi kematian akibat merokok sebesar 10 juta kematian yang mana $70 \%$ di antaranya terjadi di negara berkembang. Konsumsi rokok rata-rata $2,7 \%$ per tahun di negara berkembang, sedangkan di negara maju menurun, yaitu 1,8\% per tahun (Hudoyo, 2000). Ironisnya, prevalensi perokok di negara maju telah banyak berkurang, sedangkan perokok di negara berkembang justru makin banyak. Di negara berkembang, prevalensi perokok makin meningkat, yaitu 2,1\% per tahun (Fajriwan, 1999).

Indonesia menduduki peringkat ke 5 dalam konsumsi rokok di dunia. Dari tiga tahun (2001-2004) jumlah perokok naik dari 31,3 persen ke angka 34,4 persen atau bisa dikatakan lebih dari 50 juta orang dewasa adalah perokok. Data Survei Nasional Tahun 2004 menyebutkan bahwa 63, $2 \%$ laki-laki dan 4, $4 \%$ perempuan Inonesia adalah perokok (Aditama, 2006). Penurunan jumlah perokok terjadi, hal ini dapat dilihat berdasarkan data Riskesdas tahun 2007 yang menunjukkan proporsi perokok sebanyak29\%. Jumlah ini semakin meningkat seperti yang tertera pada data Riskesdas tahun 2010 menunjukkan jumlah perokok di Indonesia menjadi 34,7\%. ( Riskesdas 2010)

Riskesdas tahun 2010 melaporkan bahwa rata-rata umur mulai merokok secara nasional adalah 17,6 tahun dengan persentase penduduk yang mulai merokok tiap hari terbanyak pada umur 15-19 tahun. Mayoritas prevalensi penduduk yang merokok adalah perokok yang memiliki umur 15 tahun ke atas yang merokok tiap hari secara nasional adalah 28,2 persen. Sebagaimana perokok setiap hari, prevalensi perokok kadang-kadang tertinggi pada kelompok umur 15-24 tahun $(8,1 \%)$ dan cenderung menurun dengan bertambahnya umur (Riskesdas, 2010). Dari berbagai data di atas dapat disimpulkan bahwa pada umumnya usia memulai merokok diawali pada masa remaja.

Masa remaja identik dengan usia sekolah sehingga perilaku merokok remaja identik dengan perilaku merokok anak sekolah. Penelitian yang dilakukan Purnamasari, dkk (2005) yang dilakukan terhadap siswa SMP di Surakarta menunjukkan siswa yang merokok setiap hari sebesar $9,8 \%$ yang didominasi siswa laki-laki sebesar 95,6\% dan sisanya 4,4\% adalah siswa perempuan. Bayu (2008) menyatakan faktor-faktor yang memengaruhi perilaku merokok pada siswa SMP antara lain adalah iklan rokok.

Pada saat anak duduk di sekolah menengah atas, kebanyakan pada siswa laki-laki merokok merupakan kegiatan 
yang menjadi kegiatan sosialnya. Menurut mereka merokok merupakan lambang pergaulan bagi mereka. Siswa SMU yang berada dalam masa remaja yang merasa dirinya harus lebih banyak menyesuaikan diri dengan norma-norma kelompok sebaya daripada norma-norma orang dewasa. Dalam hal ini remaja menganggap merokok sebagai lambang pergaulannya. Khususnya siswa laki-laki bahwa merokok sebagai suatu tuntutan pergaulan bagi mereka. Seperti halnya yang diungkapkan oleh Hurlock (1999: 223) bahwa bagi remaja rokok dan alkohol merupakan lambang kematangan. Hal tersebut disampaikan oleh Hurlock berdasarkan fenomena di Amerika. Tetapi menurut norma yang berlaku di Indonesia lebih memandang bahwa remaja khususnya remaja yang masih berada diusia sekolah melakukan aktivitas merokok diidentikan sebagai anak yang nakal.

Hampir semua orang mulai merokok dengan alasan yang sedikit sekali kaitannya dengan kenikmatan. Dalam pikiran remaja, rokok merupakan lambang kedewasaan. Sebagai seorang remaja mereka menggunakan berbagai cara agar terlihat dewasa. Untuk membuktikannya mereka melakukan dengan sadar melakukan kebiasaan orang dewasa yakni merokok. Seperti halnya yang diungkapkan oleh Hariyadi (1997: 12) bahwa remaja ingin mencoba melakukan apa yang sering dilakukan oleh orang dewasa, dengan sembunyisembunyi remaja pria mencoba merokok karena seringkali mereka melihat orang dewasa melakukannya.

Sitepoe (2000: 20) menyebutkan bahwa alasan utama menjadi perokok adalah karena ajakan teman-teman yang sukar ditolak, selain itu juga, ada juga pelajar pria mengatakan bahwa pria menjadi perokok setelah melihat iklan rokok. Ini berarti bahwa tindakan merokok diawali dari adanya suatu sikap, yaitu kecenderungan seseorang untuk menerima atau menolak, setuju atau tidak setuju terhadap respon yang datang dari luar dalam hal ini adalah rokok. Orang melihat rokok atau melihat orang lain merokok, lalu respon apa yang muncul di dalam pikiran atau perasaannya, bisa saja orang tertarik (setuju) atau tidak tertarik (tidak setuju), hal ini akan terjadi pada setiap orang. Orang yang setuju, ada kecenderungan akan melakukannya atau menirunya, bagi yang tidak setuju tentu kencenderungannya akan menghindari. Namun ada kecenderungan lain, yaitu dalam hati ia tidak setuju, tetapi kenyataannya ia melakukannya (merokok). Hal ini tentu ada faktor lain yang mempengaruhinya. Di sinilah terjadinya kontradiksi antara sikap dan perbuatan.

Lingkungan sosial mempunyai peranan besar terhadap perkembangan remaja. Lingkungan sosial sebagai bagian dari komunitas sosial memegang peranan yang strategis bagi kehidupan sosial masyarakat. Pada masa remaja lingkungan social yang dominan antara lain dengan teman sebaya. Menurut Mappiare (1982) kelompok teman sebaya merupakan lingkungan sosial pertama dimana remaja belajar untuk hidup bersama orang lain yang bukan anggota keluarganya. Lingkungan teman sebaya merupakan suatu kelompok baru yang memiliki ciri, norma, kebiasaan yang jauh berbeda dengan apa yang ada di lingkungan rumah. Bahkan apabila kelompok tersebut melakukan penyimpangan, maka remaja juga akan menyesuaikan dirinya dengan norma kelompok. Remaja tidak peduli dianggap nakal karena bagi mereka penerimaan kelompok lebih penting, mereka tidak ingin kehilangan dukungan kelompok dan tidak ingin dikucilkan dari pergaulan. Sebagian dari remaja mengambil jalan pintas untuk menghindarkan diri dari masalah sehingga cenderung untuk keluyuran dan melakukan tindakan pergaulan yang salah dengan teman-temannya. 
Akibatnya banyak yang terjerumus dalam tindak kenakalan seperti menipu, berkelahi, mencuri dan sebagainya.

Pada pengertian lain Hurlock (2001) mengatakan bahwa seseorang yang memiliki ciri tertentu secara berlebihan bisa menimbulkan penerimaan yang kurang baik, meskipun ciri itu sendiri merupakan ciri yang sangat dikagumi. Sebagai contoh individu akan memiliki peluang yang lebih besar untuk dapat diterima dalam masyarakat bila dia murah hati daripada bila dia kikir. Akan tetapi, bila dia terlalu murah hati, membagi-bagikan hadiah begitu saja kekanan kiri, mungkin akan timbul kesan bahwa dia mencoba 'membeli' dukungan. Pergaulan dengan teman sebaya serta akibat yang ditimbulkan merupakan hal yang sangat penting sebab menciptakan perilaku dan bentuk tingkah laku yang akan dibawanya ketika dewasa. Remaja mudah terjebak atau terlibat pada perbuatan-perbuatan yang menyimpang. Banyak remaja yang punya keinginan tampil beda, namun ada beberapa remaja yang salah jalur dalam menunjukkan jati dirinya. Remaja kadang bertingkah laku di luar kewajaran seperti minumminuman keras atau terjerumus dalam perkara kriminal.

Perilaku anti sosial ini sering terjadi karena dipengaruhi perilaku teman-

\section{Metode}

Jenis Penelitian yang digunakan adalah kuantitatif dengan desain cross sectional. Populasi adalah seluruh siswa SMA X. Cara pengambilan sampel dengan menggunakan teknik acak stratifikasi (Stratified random sampling). Penentuan strata berdasarkan tingkatan

\section{Hasil penelitian}

Distribusi perilaku merokok remaja di SMAN X paling banyak responden adalah bukan perokok yaitu 250 orang $(78,1 \%)$ sedangkan untuk perokok 70 orang (21,9\%). Distribusi tersebut menunjukkan bahwa sebagian besar temannya untuk melakukan tindakan yang tidak baik. Remaja cenderung untuk mengikuti kemauan temantemannya agar tidak merasa ditolak atau diabaikan oleh kelompok teman sebayanya (Prasetyo, 2001).

Pada kehidupan sehari-hari remaja lebih dekat dengan teman sebaya daripada dengan orangtua karena remaja menginginkan teman yang mempunyai minat, sikap, yang sama, sehingga banyak melakukan kegiatan bersama, dalam mengisi waktu luangnya. Hal ini dipertegas oleh Bee (dalam Amin, 1999) yang menyatakan bahwa remaja cenderung melakukan hal-hal yang sama dengan teman-temannya semata-mata agar dapat diterima dan tetap menjadi anggota kelompok tersebut. Persamaan dalam usia, pendidikan, jenis kelamin dan perasaan terabaikan membuat mereka menjalin persahabatan yang kental dan erat dengan kesetiakawanan. Akibatnya apabila salah satu dari mereka merasa menderita, maka yang lainnya akan siap membantu menghilangkan penderitaan itu.

Tujuan dari penelitian ini adalah mengetahui hubungan antara faktor lingkungan sebaya dengan perilaku merokok pada siswa SMA $X$ di Kabupaten Tasikmalaya tahun 2013.

kelas yaitu ;. Jumlah sampel 320 sampel.Pengumpulan data dilakukan dengan menggunakan alat bantu angke/t kuesioner yang diisi langsung oleh responden. Analisis yang dilakukan diawali dengan analisis univariat, kemudian dilanjutkan dengan analisis bivariat menggunakan uji chi square

responden penelitian ini tergolong bukan perokok Lingkungan sebaya dikategorikan menjadi dua kategori yaitu baik dan tidak baik. Seorang responden dikategorikan memiliki lingkungan sebaya baik jika memiliki skor $\geq$ median tidak baik jika memiliki skor < median. 
Berdasarkan data yang diperoleh, besarnya nilai median untuk variabel Lingkungan sebaya adalah 5 . Berdasarkan tabel 5.2 di atas tampak bahwa, dari 320 orang responden 155 $(48,4 \%)$ memiliki lingkungan sebaya yang tergolong baik; sedangkan 165 $(51,6 \%)$ memiliki lingkungan sebaya yang tergolong tidak baik.

Hasil analisis hubungan antara lingkungan teman sebaya dengan perilaku merokok diperoleh bahwa ada sebanyak $22(42,3 \%)$ remaja dengan lingkungan teman sebaya baik sebagai

\section{E. Pembahasan}

Hasil penelitian menunjukkan ada sebanyak $22(42,3 \%)$ remaja dengan lingkungan teman sebaya baik sebagai perokok, sedangkan di antara remaja dengan lingkungan teman sebaya tidak baik ada $48(60,8 \%)$ perokok. Hasil analisis bivariat diperoleh nilai $\mathrm{p}=$ 0,058 maka dapat disimpulkan tidak ada hubungan yang signifikan antara lingkungan teman sebaya dengan perilaku merokok pada remaja. Hal ini sesuai dengan penelitian Dian Komasari pada tahun 2007 bahwa perilaku merokok tidak berhubungan dengan pengaruh lingkungan sebaya.

Perilaku merokok bagi remaja terutama remaja putra sering diidentikkan dengan kegagahan dan kedewasaan. Pada umumnya, perilaku merokok yang timbul di kalangan remaja disebabkan oleh beberapa faktor. Salah satunya adalah pengaruh lingkungan (teman sebaya). Lingkungan teman sebaya dapat mempengaruhi timbulnya perilaku merokok karena adanya konformitas remaja terhadap kelompok sebayanya. Hal ini dilakukan karena adanya kebutuhan remaja untuk diterima secara sosial oleh lingkungannya dan dapat membawa ke arah penerimaan kelompok teman sebaya.

Dari hasil analisis diperoleh pula nilai $\mathrm{OR}=2,111$, artinya lingkungan perokok, sedangkan di antara remaja dengan lingkungan teman sebaya tidak baik ada $48(60,8 \%)$ perokok. Hasil uji statistik diperoleh nilai $\mathrm{p}=0,058$ maka dapat disimpulkan tidak ada hubungan yang signifikan antara lingkungan teman sebaya dengan perilaku merokok pada remaja. Dari hasil analisis diperoleh pula nilai $\mathrm{OR}=$ 2,111 , artinya lingkungan teman sebaya tidak baik mempunyai peluang 2,11 kali untuk merokok dibanding lingkungan teman sebaya baik.

teman sebaya tidak baik mempunyai peluang 2,11 kali untuk merokok dibanding lingkungan teman sebaya baik. Hal ini sejalan dengan penelitian yang dilakukan oleh Sunggoro (2006) bahwa lingkungan dari teman sebaya memberikan sumbangan efektif dalam berperilaku merokok.

Dalam perkembangan sosial remaja maka remaja mulai memisahkan diri dari orang tua dan mulai memperluas hubungan dengan teman sebaya. Pada umunya remaja menjadi anggota kelompok teman sebaya (peer group). Kelompok sebaya menjadi begitu berarti dan sangat berpengaruh dalam kehidupan sosial remaja. Kelompok sebaya juga merupakan wadah untuk belajar kecakapan-kecakapan sosial karena melalui kelompok remaja dapat mengambil berbagai peran. Di dalam kelompok sebaya remaja menjadi sangat bergantung kepada teman sebagai sumber kesenangan dan keterikatannya dengan teman sebaya begitu kuat. Kecenderungan keterikatan (kohesi) dalam kelompok tersebut akan bertambah dengan meningkatnya frekuensi interaksi di antara anggotaanggotanya (Soetjiningsih, 2004).

Pengaruh teman terjadinya penggunaan rokok sangat besar. Pola interaksi remaja yang lebih banyak dihabiskan dengan teman sebaya juga akan berpengaruh terhadap 
pembentukan perilaku remaja. Fenomena yang ada adalah sebagian besar dari anggota kelompok remaja memiliki kebiasaan merokok. Fakta yang diperoleh di antara remaja perokok dan nonperokok, $87 \%$ mempunyai

\section{F. Simpulan dan saran}

1. Distribusi tersebut menunjukkan bahwa sebagian besar responden penelitian ini tergolong bukan perokok.

2. 320 orang responden $155(48,4 \%)$ memiliki lingkungan sebaya yang tergolong baik; sedangkan 165 $(51,6 \%)$ memiliki lingkungan sebaya yang tergolong tidak baik.

3. Hasil analisis hubungan antara lingkungan teman sebaya dengan perilaku merokok diperoleh bahwa ada sebanyak $22 \quad(42,3 \%)$ remaja dengan lingkungan teman sebaya baik sebagai perokok, sedangkan di antara remaja dengan lingkungan teman sebaya tidak baik ada $48(60,8 \%)$ perokok. Hasil uji statistik diperoleh nilai $\mathrm{p}=0,058$ maka dapat disimpulkan tidak ada hubungan yang signifikan antara lingkungan teman sebaya dengan perilaku merokok pada remaja.

Saran yang direkomendasikan adalah optimalisasi orang tua dalam memberikan contoh, kemampuan mengontrol teman sebaya serta berkontribusi langsung dalam pendidikan moral kepada anaknya.

\section{G. Referensi}

Antoro., Jehani,L., 2006, Mencegah

Terjerumus Narkoba, Visimedia, Tangerang

Azwar.E., 2007, Determinan Perilaku Merokok Pada Mahasiswa Fakultas Kesehatan Masyarakat Universitas Muhammadiyah Aceh Provinsi Nangroe Aceh Darussalam, Tesis, Universitas Gadjah Mada, Yogyakarta sekurang-kurangnya satu atau lebih sahabat yang merokok. Semakin banyak remaja merokok, semakin besar kemungkinan teman-temannya merokok pula (Gandara, dkk, 2007).

Effendy, N., 1998, Dasar-Dasar

Keperawatan Kesehatan

Masyarakat, EGC, Jakarta

Fatmawati, 2006, Materi Bahaya Rokok

Untuk Kurikulum Sekolah,

http://www.sinarharapan.co.id/berit a/0609/15/opi01.html)

Gandara.S., Yamin.A., Taryono.Y., 2007, Prilaku Merokok Pada

Remaja SMP,

http://metlit.blogspot.com/

Hikmat.M., 2007, Awas Narkoba Para Remaja Waspadalah, PT Grafitri, Bandung

Indukirana. A., 2006, Hubungan Pengetahuan Dan Lingkungan Sekitar Dengan Perilaku Merokok, Fakultas Kedokteran Universitas Gadjah Mada Yogyakarta, Skripsi, Yogyakarta

Jabbar, A., 2008, Ngerokok Bikin Kamu Kaya, Samudera, Sukoharjo Solo

Lemeshow, S., Jr Hosmer.D.W., Klar.J., 1997, Besar Sampel dalam

Penelitian Kesehatan, Gadjah

Mada University Press,

Yogyakarta

Monks.F.J., Knoers.A.M.P, Haditono,

S.R, 2002, Psikologi

Perkembangan, Gadjah Mada

University Press, Yogyakarta

Murti, B. 2003. Prinsip dan Metode

Riset Epidemiologi, Jilid Pertama, Edisi Kedua, Gadjah Mada

University Press, Yogyakarta.

Musthofa.A.S., 2002, Problem

Narkotika-Psikotropika dan

HIV/AIDS, Zikrul Hakim, Jakarta

Timur

Notoatmodjo.S., 2005, Promosi

Kesehatan Teori dan Aplikasi,

Rineka Cipta, Jakarta 
Notoatmodjo.S., (2003), Ilmu Kesehatan Masyarakat Prinsip-Prinsip Dasar, PT Rineka Cipta, Jakarta

Notoatmodjo.S., 2002, Metodologi

Penelitian Kesehatan, Rineka Cipta, Jakarta
Priangan online, 2007, "Perokok Remaja Capai 30 Persen" Tasik Butuh Kawasan Bebas Rokok, http://prianganonline.com Purwanto, H.,2002, Pengantar Perilaku Manusia untuk Keperawatan, EGC, Jakarta 